\title{
Are Lower Private Equity Returns the New Normal?
}

By Eileen Appelbaum and Rosemary Batt*

June 2016

$\begin{array}{lll} & \text { Center for Economic and Policy Research } & \\ & \text { Suite } 400 & \text { tel: } 202-293-5380 \\ & \text { Washington, DC } 20009 & \text { fax: 202-588-1356 } \\ & & \text { www.cepr.net }\end{array}$




\section{Contents}

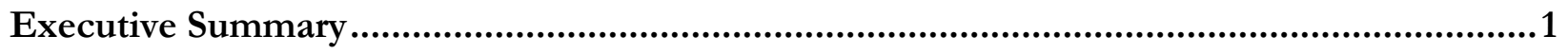

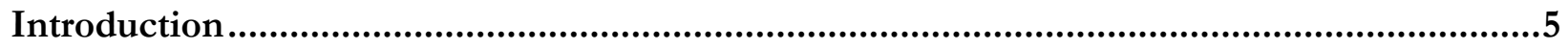

Measuring the Performance of Private Equity Funds .........................................................7

What is the Appropriate Measure of Fund Performance? ..................................................................... 8

Estimating the Value of Companies Still in Fund Portfolios...........................................................10

How Risky Is Investing in Private Equity? ................................................................................... 12

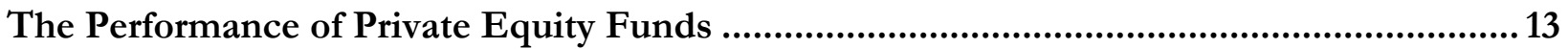

Recent Academic Studies of Private Equity Fund Performance .......................................................15

How Persistent Is the Performance of PE Buyout Funds? .............................................................23

PE Fund Performance over Time Using the PME and IRR ..........................................................26

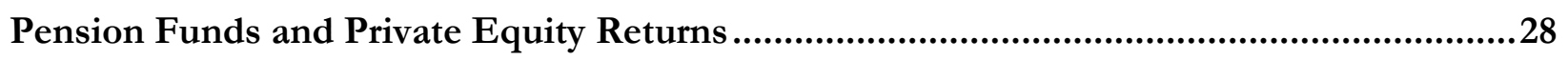

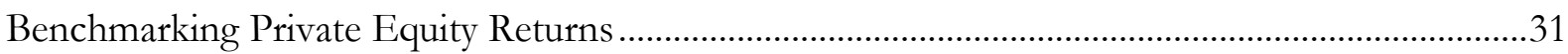

PE Buyout Fund Returns and Pension Fund Investments in Private Equity .................................33

Conclusion: What Lies Ahead for PE Fund Performance? .................................................34

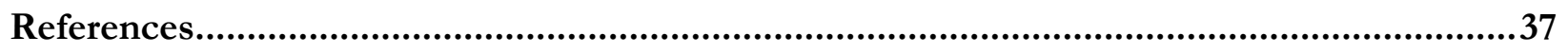

\section{Acknowledgements}

We thank Dean Baker, Steven Berkenfeld, Peter Morris, Ludovic Phallipou and Susan Webber for comments on earlier drafts of this report. 


\section{Executive Summary}

U.S. private equity fundraising had its best year since the financial crisis in 2015 — raising $\$ 185$ billion. But is the enthusiasm of investors warranted? Do PE buyout funds deliver outsized returns to investors and will they do so in the future? This report answers this question by reviewing the most recent empirical evidence on buyout fund performance; the answer is no. While median private equity buyout funds once beat the S\&P 500, they have not done so since 2006 -- despite industry claims to the contrary.

\section{Measuring Private Equity Performance}

Reports of the performance of PE buyout funds depend importantly on how returns on investment are measured. The private equity industry has long relied on the "internal rate of return" (IRR) as its primary performance measure, but that metric has been widely discredited - not only in the academic finance community but among management consulting firms such as McKinsey \& Company as well. Using the IRR makes investments look much better than they actually are.

In contrast to private equity general partners, most finance economists measure fund performance using a metric known as the "public market equivalent" (PME). This measure compares returns from investing in private equity with returns from comparable, and comparably timed, investments in the stock market, as measured by the S\&P 500 or other stock market indexes. This measure provides limited partners with more reliable information about two things: how much money they get back at the end of their 10-year investment in a PE fund relative to their initial investment, and how that compares with the return they would have earned if they had invested in some other asset instead — say in companies that trade on the stock market.

The typical 10-year life of a PE fund means that the actual realized returns cannot be known until the fund is liquidated after 10 years. Investors, however, are anxious to know how the funds are performing each year. For this purpose, private equity general partners calculate annual fund performance based on interim evaluations of unsold portfolio companies. While national accounting standards implemented in 2008 require these evaluations to be based on "fair value," general partners have wide discretion in the assumptions they use to calculate the value of unsold portfolio companies. As a result, actual returns realized by limited partners when the fund is liquidated may fall short of interim estimates.

Finally, another challenge for investors in private equity buyout funds is adjusting returns for the greater riskiness of these investments compared to investments in the stock market when measuring performance. We identify the many risks associated with investing in these funds in this paper. For 
example, compared to publicly-traded corporations, PE portfolio companies are more sensitive to market conditions and more subject to financial distress or bankruptcy because of the much higher debt burden they carry after a leveraged buyout. Industry analysts and most investors generally assume that PE buyout funds need to make returns that exceed stock market returns by at least 3 percent to compensate for the added risks.

In sum, whether the returns to investing in private equity buyout funds justify the high fees and greater risks associated with these investments is an empirical question that depends importantly on which performance metrics are used, how the values of unsold portfolio companies are calculated, and how reported returns are risk-adjusted.

\section{Key Findings from Recent Economic Studies of PE Fund Performance}

In our 2014 detailed review of private equity fund performance (Appelbaum and Batt 2014), we found that the PE industry, using the internal rate of return, reported substantially higher returns to private equity than did finance economists using the public market equivalent. Studies by finance economists available at that time found that the median (or typical) buyout fund outperformed the S\&P 500 by about 1 percent per year, and the average fund by between 2 and 2.5 percent annually - an outperformance that falls short of the 3 percent widely viewed as necessary to compensate the limited partners for the added risks associated with investing in PE buyout funds.

An important new study that includes more recent data documents a downward trend in private equity buyout performance. The researchers found that the median PE buyout fund outperformed the S\&P 500 by 1.75 percent annually in the 1990 s and 1.5 percent in the 2000 s, but performed about the same as the S\&P 500 since 2006 (Harris, Jenkinson, and Kaplan 2015). Other analyses reach similar conclusions (PitchBook 2015b). Moreover, the performance of PE buyout funds is worse when compared to a stock market index based on mid-cap companies more comparable to those found in private equity portfolios rather than one based on large-cap companies, as in the S\&P 500 .

Another important question for investors in PE funds is whether they can rely on a general partner's track record in deciding where to invest. Can investors assume that if an initial fund produces strong returns, then a follow-on fund managed by the same general partner will likewise yield strong results? In the period before 2000, the answer was yes: a GP with a top performing fund had a high probability that the follow-on fund would also be top performing. But since 2000, the answer is no, according to recent research by finance economists (Harris, Jenkinson, and Kaplan 2014; Braun, Jenkinson, and Stoff 2015). Thus, while limited partners used to be able to rely on the past performance of general partners to guide future investment decisions, recent evidence shows they 
can no longer do so. That is, there is a "lack of persistence" in performance of the buyout funds of general partners over time. A general partner's past performance managing a buyout fund is no longer a good predictor of future performance (Harris, Jenkinson, and Kaplan 2014; Braun, Jenkinson, and Stoff 2015).

\section{Why Has PE Buyout Performance Declined?}

Several factors explain the declining performance of private equity buyout funds - most importantly, changes in economic conditions and the competitive landscape. The perception that PE buyout funds outperform the stock market rests primarily on their performance in the 1980s and 1990s, when a handful of buyout firms exploited the poor performance of large U.S. conglomerates by acquiring poorly performing divisions and selling them later for more than they paid. The use of high levels of debt to acquire portfolio companies goosed returns. In the early 2000 s, private equity funds took advantage of the stock market bubble - selling portfolio companies at higher prices than they paid for them as the stock market continually rose. Low interest rates fueled high levels of debt financing, which continued to fuel outsized earnings until the market crashed in the financial crisis.

Today, the private equity industry claims it has moved far beyond the poor fund raising and performance during the financial crisis - citing the high distributions returned to investors during the stock market run up of 2013 and 2014 and the subsequent fundraising bonanza of 2015. But these distributions make up for several years during and after the financial crisis in which few distributions were made. And, as recent studies show, despite the large distributions, private equity investments have generally failed to beat the even more buoyant returns of the stock market. In the meantime, the fundamentals of the industry have changed. By 2016, 4,100 private equity firms headquartered in the U.S. were competing against one another to acquire portfolio companies in an environment in which the number of high-performing, undervalued target companies is shrinking. In addition to the $\$ 185$ billion raised in 2015 , buyout funds held another $\$ 460$ billion in unspent funds - or "dry powder" - from prior rounds of fundraising. And since the crisis, they've faced steep competition from large publicly-traded corporations with deep cash reserves seeking to make strategic acquisitions of the most sought after companies.

These competitive conditions disproportionately disadvantage private equity funds as they face worse credit ratings and higher costs of debt than the "strategics," due in part to guidance set by bank regulators in the last few years that limits bank lending on leveraged buyout deals. Finally, PE distributions have been high in recent years because the stock market surged as the economy recovered from the recession. But research shows that buying companies when the stock market is at or near a peak and prices for target companies are high — as in the current period — yields 
substantially lower returns when these investments are subsequently exited (Robinson and Sensory 2011, 2015).

Despite these new realities, PE firms — if not PE investors — are continuing to reap high returns fueled in large measure by the high (and sometimes hidden) fees they charge their limited partners and portfolio companies (Appelbaum and Batt 2016). As we show in this paper, most investors in private equity buyout funds will find that PE's promise of superior performance is elusive: for most investors, PE returns now more or less match the market. Moreover, the negative impact of private equity leveraged buyouts on workers and main street companies is well documented - including lower wages and employment growth in their portfolio companies and the higher likelihood of financial distress and bankruptcy of those companies due to increased debt levels (documented in Appelbaum and Batt 2014). Given these negative effects, employee pension funds, university endowments, and other investors with a broad public purpose require a compelling reason to invest in buyout funds. In the past, the promise of high returns may have served to justify investing in PE buyout funds. Today, promises of high returns are likely to be disappointed. 


\section{Introduction}

"Buyout fund returns have exceeded those from public markets in almost all vintage years before

2006. Since 2006, buyout fund performance has been roughly equal to those of public markets."

Robert S. Harris, Tim Jenkinson, and Steven N. Kaplan

The private equity industry grew rapidly from 2000 through the bubble years before collapsing during the Great Recession; but by 2010 it was on the mend, and since then its investments have surpassed its early growth period. Pension funds and other institutional investors are investing more now than ever in private equity buyout funds. While these PE funds invested roughly $\$ 100$ billion annually to acquire U.S. companies in the early 2000s, they have invested almost $\$ 500$ billion annually since 2010 - for a cumulative total of over $\$ 5.7$ trillion, according to the investment research firm PitchBook.

Why is private equity fundraising once again booming? Notably, after several years of poor payouts during and after the recession, PE buyout funds were able to capitalize on a rising stock market to exit companies acquired before the crisis, and in turn make substantial distributions to investors after 2011. With distributions exceeding contributions, cash-rich pension funds and other institutional investors were again willing to plough money back into new PE funds. Fundraising in the 2013-2015 period was substantially higher than the 2010-2012 period, with a total of \$185 billion raised by U.S. private equity funds in 2015 alone (PitchBook 2015a). Overall, U.S. PE funds in 2015 averaged 112 percent of their fund targets and reached fund closings faster than at any time since 2006. Institutional investors are competing for opportunities to participate in funds that are viewed as more desirable. With their renewed bargaining power, PE buyout funds are exploring new fee structures to enhance their own returns (Bain \& Company 2016 p. 5-7) - despite the fact that they already extract millions in fees from their limited partners each year (Appelbaum and Batt 2016). The average size of funds has also risen steadily, and mega-funds and mega-deals are back in play.

But is this enthusiasm warranted? Do PE buyout funds still deliver outsized returns to investors? Industry participants claim that these funds significantly outperform the stock market, but finance economists who study the industry have found considerably more modest results (Appelbaum and Batt 2014). In this report, we analyze recent research by finance economists which shows that the overall performance of private equity funds has been declining. While private equity buyout funds once beat the S\&P 500, the median buyout fund has not done so since 2006 (Harris, Jenkinson, and Kaplan 2015; L'Her, Stoyanova, Shaw, Scott, and Lai 2016; PitchBook 2015b). 
These findings raise serious questions about whether the current investment explosion in PE buyout funds will pay off for pension funds and other institutional investors. Will newly-minted PE funds be able to acquire target companies that they can sell later at substantially higher prices? Changes in the competitive landscape cast doubt on their ability to do so. In the 1980s and 1990s, it was easy to make outsized returns on leveraged buyouts: a small number of buyout firms had many opportunities to break up large conglomerates and "unlock value." But by 2016, 4,100 private equity firms were headquartered in the U.S., raising 696 buyout funds, according to the PE lobbying group, American Investment Council (2016) - formerly the Private Equity Growth Capital Council. The latest round of fundraising is on top of $\$ 460$ billion of uncommitted capital in existing buyout funds — so called "dry powder" - capital that limited partners have committed to PE buyout funds but that has not been spent because these private equity funds have not found attractive buyout targets (Bain 2016 p. 10; AIG 2016).

Private equity firms with too much cash on hand are also competing with publicly-traded corporations that have deep cash reserves for strategic acquisitions. This has led to "sky-high acquisition prices," according to a 2016 Bain \& Company report, with "multiples" — the ratio of the purchase price to enterprise value - at 10 times EBITDA (earnings before interest, taxes, depreciation, and amortization) by early 2015. This is higher than the multiples of acquisitions in the bubble years. Moreover, while the "strategics" benefit from investment-grade credit ratings that lower the cost of debt, private equity firms face worsening credit conditions and weaker bank lending in light of new guidance set by bank regulators (Bain \& Company 2016 p. 12). Under these new guidelines, banks are strongly encouraged to limit lending for deals to no more than 6 times EBIDTA (Board of Governors of the Federal Reserve System et al. 2013). Carlyle's 2016 acquisition of Veritas, the largest LBO in 2015, is a case in point. The deal was delayed 6 months while the banks negotiated to meet the new requirements and to address increased earnings uncertainty. Carlyle had to reduce leverage from 6.7 times to 5.8 times EBITDA and raise the equity portion of the deal from 33 percent to 40 percent of the purchase price. ${ }^{1}$

Private equity returns are also cyclical and mirror stock market trends, according to new research by finance economists, which we review in this report. PE distributions have been high in recent years because the stock market surged as the economy recovered from the recession. But buying companies when the stock market is at or near a peak and prices for target companies are high — as in the current period - yields substantially lower returns than buying at the trough when prices are low (Robinson and Sensory 2011, 2015).

1 Davis and Natarajan (2016). 
In sum, the new research that we review in this report is critical for private equity investors to consider. Fully a third of the capital in private equity funds comes from U.S. pension funds (Bain \& Company 2013). They are responsible for investing the savings of millions of Americans. Other major investors include university endowments, non-profit foundations, and insurance companies, whose fortunes rise and fall with their investment choices. This new research shows both that private equity performance is cyclical, mirroring the stock market, and that it has a downward trajectory. Moreover, it also shows that the past performance of a private equity firm's general partners is no longer a good predictor of future performance (Harris, Jenkinson, and Kaplan 2014; Braun, Jenkinson, and Stoff 2015).

We begin by explaining the different ways in which private equity returns are measured and why some are more appropriate than others. We then review the most credible new research on the performance outcomes of private equity funds and their persistence over time.

\section{Measuring the Performance of Private Equity Funds ${ }^{2}$}

"Measurement issues" in finance are often viewed as too technical or boring for the typical investor or public citizen to pay attention to. But they are central to understanding whether investing in private equity funds is worthwhile. A central problem is that independent analyses of returns are difficult to carry out because of private equity's notable lack of transparency and insistence on confidentiality. Private equity firms report net returns to their limited partner (LP) investors, but do not make this information available to others; nor do they tell their LP investors how they arrive at this measure of fund performance. Data available to researchers is improving, but no comprehensive, unbiased, and widely available data yet exists that can be used to evaluate PE performance. All studies of PE performance suffer from uncertainty about just how representative the data on fund returns actually is. As private equity researchers Robinson and Sensoy note:

'Ultimately, however, the universe of private equity funds is not available, and summary statistics from [various sources] differ systematically from one another. Consequently, it is impossible to know whether any differences are a function of sample selection, self-reporting, and survivorship biases that creep into commercially available data sources, whether they reflect characteristics of the LP/GP matching process in private equity, or whether they are evidence of sample selection bias..." (2014 p. 13)

Beyond the adequacy of data, three important measurement issues need to be addressed at the outset. The first concerns which metric is used to actually measure performance. While the private

2 These issues are discussed at greater length in Appelbaum and Batt (2014). 
equity industry has continued to report returns based on the "internal rate of return," finance economists have shown why this metric is seriously flawed and should be replaced by a "public market equivalent" index, which takes into account the opportunity costs of investing in PE buyout funds versus other alternatives. The second issue concerns the measurement of unrealized returns, which arises because limited partners typically make a commitment of capital to a private equity fund and are locked into that commitment for the life of the fund - usually 10 to 12 years. But investors need to know about the returns to active funds in a more timely fashion. To do so, they must rely on estimates by the fund's general partner of unrealized returns - that is, estimates of the value of companies still in PE portfolios. And general partners vary widely in the assumptions and methods they use to arrive at these estimates. A third issue is more intangible: how to evaluate the wide range of risks that the limited partners assume when they invest in private equity and how they should be compensated for that risk.

\section{What is the Appropriate Measure of Fund Performance?}

The internal rate of return (IRR) is widely used by PE industry participants as a measure of PE fund performance. The IRR is the interest rate (also known as the discount rate) that will bring a series of realized and future cash flows (positive and negative) to a net present value equal to the value of cash invested. The IRR formula can be very complex depending on the timing and variations in cash flow amounts. One of the disadvantages of using IRR is that all cash flows are assumed to be reinvested at the same discount rate, although in the real world these rates will fluctuate. The IRR suffers from three main flaws that make it a poor measure of fund performance. ${ }^{3}$

Computational difficulties. The calculation of the IRR is an iterative process carried out by a computer. Under certain conditions, it either does not converge to a value for IRR or it yields multiple results. This can happen if the cash flows used to compute the IRR change direction from positive to negative or negative to positive more than once over the time period under consideration. This is not uncommon in the case of private equity.

$I R R$ calculation assumes distributions are reinvested at same IRR rate. In the calculation of the IRR, the high IRR earned from an early distribution is assumed to apply to these distributed funds in subsequent periods. That is, the mechanics of the IRR computation assume that the pension fund or other investor that receives the distribution has the opportunity to reinvest it at the same high IRR as the initial PE investment. This will rarely be the case. Thus the calculation exaggerates the return from private equity investments during the life of the PE fund and does a poor job of predicting the

3 For numerical examples that illustrate these points, see Appelbaum and Batt (2014 p. 168-171). For a detailed discussion, see Phalippou (2009). 
actual return that will be realized when the fund reaches the end of its life span and is liquidated (Jenkinson, Sousa, and Stucke 2013 p. 14).

Opportunities to game the calculation. The IRR is sensitive to the timing of distributions from a private equity fund. Early sales of high performing companies in the PE fund's portfolio raise the measured IRR. Decisions about when to sell portfolio companies and distribute the returns to investors are made by the fund's general partner (GP). The GP is typically a management committee drawn from the private equity firm's partners. The GP manages the fund and makes all decisions; investors in the fund are limited partners (LPs) and have no decision making power, including no say over the acquisition or subsequent sale of portfolio companies. This characteristic of the IRR provides GPs with an incentive to increase the fund's IRR by engaging in early sales of successful portfolio companies even when these sales do not make economic sense and/or are not in the best interests of limited partners.

Averaging the IRR across multiple funds in an investor's portfolio or lining the funds up end-to-end and treating all of the investments and returns as if they were a single fund - from time zero when the first investment was made to the current year - can also lead to exaggerated results. This is especially problematic if funds with earlier vintages yield higher returns than those of more recent vintages.

McKinsey \& Company highlighted the key problems in using the IRR as a performance metric in a 2004 article in the McKinsey Quarterly. They noted that, "[f]or decades, finance textbooks and academics have warned that typical IRR calculations build in reinvestment assumptions that make bad projects look better and good ones look great... We believe that managers must either avoid using IRR entirely or at least make adjustments for the measure's most dangerous assumption: that interim cash flows will be reinvested at the same high rates of return" (Kelleher and MacCormack 2004).

These well-known flaws in the IRR as a measure of PE fund returns led finance economists Steven Kaplan and Antoinette Schoar to develop an alternative method for calculating these returns - the Public Market Equivalent (PME). In their seminal and widely-cited study of private equity returns, Kaplan and Schoar (2005) developed the PME, which compares returns from investing in private equity with returns from comparable, and comparably timed, investments in the stock market, as measured by a stock market index, typically the S\&P 500. The PME is more useful than the IRR for the LP investors because they need to assess their returns relative to what investments in the stock market or alternative indexes would yield. They care about two questions: how much money they get back by the end of the 10-year period (during which they are locked into the PE fund) relative to 
their initial investment, and how that compares with the return they would have earned had they invested the same amount of capital in another way - say, in the shares of companies that trade on the stock market.

A PME equal to 1 means that the return from investing in the buyout fund just matches the return from an equivalent and similarly timed investment in the stock market. A PME greater than 1 indicates that the return from investing in the PE fund was greater than what could have been earned in the stock market; a PME less than one indicates a return from PE investments that is less than the stock market return. A PME of 1.27, for example, means that the PE fund outperformed the stock market by 27 percent over the life of the fund. If the fund has a life of 10 years, this implies an average annual outperformance of just over 2.4 percent.

The PME is the preferred metric of finance economists for evaluating fund performance. It avoids the problems associated with the use of the IRR for this purpose. It also produces interim results that more closely predict fund performance over the life of the PE fund.

An additional concern is that even when the public market equivalent is used, as it is in most of the studies we review below, researchers typically use the S\&P 500 to compute the PME. The S\&P 500, however, is based on publicly-traded corporations that are substantially larger than those typically acquired by private equity buyout funds. A stock market index tailored to better match the PE funds' own portfolio of companies provides a more accurate (and often less flattering) measure of risk-adjusted fund returns. Some of the studies reviewed below make use of a variety of stock market indexes, including those more tailored to PE fund investments in portfolio companies. These results are usually less favorable to PE fund performance.

\section{Estimating the Value of Companies Still in Fund Portfolios}

In their 2005 study, Kaplan and Schoar examined fund returns over the period 1980-2001 in which all (or virtually all) portfolio firms had been sold and the fund had been liquidated. Thus, their calculations were based on actual realized returns to the limited partners and not on subjective estimates by general partners of the value of companies still held in their fund's portfolio. In that study, Kaplan and Schoar found that the returns to limited partners from these investments are highly variable, and on average, are slightly lower than what they would have earned by investing in the S\&P 500 index. Kaplan and others have since raised questions about the quality of the data available for that study, so we will not dwell on the results. In the next section of this paper we will report on the results of more recent studies of PE fund performance. What is important for the present discussion is that Kaplan and Schoar's 2005 study used data from funds that had been liquidated. Most other studies of PE fund performance include large numbers of active PE buyout 
funds and calculate fund returns by relying on interim valuations of the unsold portfolio companies held by these funds. The value of an active fund (its net asset value, or NAV) is calculated as the realized value of investments that have already been sold plus an estimate by the GP of the market value of unsold companies held in the fund's portfolio. In these cases, the calculation of PE fund performance necessarily relies on estimates by the GP of unrealized returns.

New accounting standards implemented in 2008 require PE funds to report the values of unsold companies in their portfolios at "fair value." This is defined as "the price that would be received to sell an asset or paid to transfer a liability in an orderly transaction between market participants as of the measurement date." 4

The standard requires that unobservable inputs used in determining the fair value of an investment must incorporate the assumptions a market participant would use in developing an exit price. The PE fund can use its own data to develop the unobservable inputs used to arrive at the estimated fair value; but only the assumptions and not the data must be disclosed. Thus, a PE fund must outline a clear valuation process, but the fund's GP has full discretion in the choice of approach, which unobservable inputs are used, and the range of values for the inputs used to arrive at fair market value.

Thus, the standard gives the GP a lot of wiggle room in valuing companies in the fund's portfolio. Assumptions about key inputs - the discount rate, projected revenue growth, and profit margins among others - may lie within a reasonable range. But there is still a lot of guesswork embedded in assumptions about the range of values that each unobservable variable can take on, especially in determining where in this rather wide range the portfolio company falls. Choosing different values within that range for unobservable inputs can lead to wide differences in the valuation of the company. Clarification of the rules for Fair Value Measurement issued in May 2011, cited in Gottlieb (2011), makes it clear that PE funds do not have to provide quantitative sensitivity disclosures to investors. That is, PE funds do not have to report to investors the potential impact of various assumptions on the valuation arrived at for the company. The general partner simply presents its view of the value of companies in the PE fund's portfolio to the fund's limited partners; the LPs have no way to independently evaluate the accuracy of the GP's estimates.

It is important to recognize that calculations of industry-wide PE fund performance are based on estimates by GPs of the value of large numbers of unsold companies; reported gains are largely the

4 In September 2006 the U.S. Financial Accounting Standards Board (FASB) issued the Statement of Financial Accounting Standards SFAS) No. 157. Paragraph 5 of SFAS No. 157 (known today as ASC 820 in the updated FASB Codification) requires PE funds to report portfolio companies at fair value. Funds have had to report fair value since December 2008. 
unrealized gains attributed to these companies by GPs. For example, in 2015 CalPERS for the first published time what it pays to private equity firms in performance fees (also known as carried interest); one third of these fees were based on unrealized carry — that is, carry attributed to expected gains from sales of portfolio companies mostly acquired in the prior several years. ${ }^{5}$ These companies were acquired at very high price-to-earnings ratios. It is likely that GP estimates of the value of their PE funds reflect these high prices, which will be difficult to match when these companies are resold.

\section{How Risky Is Investing in Private Equity?}

It is important to understand that investments in private equity carry risks that are specific to this asset class. These include: ${ }^{6}$

$>$ Leverage Risk: This is the potential for default and bankruptcy when portfolio companies are loaded with excessive amounts of debt. For example, PE-owned Caesar's Entertainment exemplifies how a portfolio company bought at a high multiple of earnings in a leveraged buyout with a high level of debt can become bankrupt and investors can lose the equity they invested in the company. ${ }^{7}$

$>$ Operating and Business Risk: Some companies acquired by private equity funds may involve exceptional operating and business risks. Investments in oil and gas production, for example, may be subject to wild and unpredictable swings in energy prices. Energy Future Holdings, the largest leveraged buyout in history at $\$ 48$ billion, went bankrupt because the private equity owners bet on the price of natural gas rising and instead it collapsed (Appelbaum and Batt 2014 p. 224-227).

$>$ Liquidity Risk: Investments by limited partners in private equity funds are typically for a 10 -year time period; funds can't be withdrawn if there are economic changes that make it desirable to exit the investment. The secondary market generally provides limited opportunities for pension funds to sell their stakes in private equity funds.

$>$ Commitment Risk: The uncertain timing of capital calls and distributions, which are controlled by the PE fund's general partner, is a risk for the limited partners that invest in the fund. The LPs may face difficulties when commitments are called on short notice or when distributions they are counting on are delayed.

> Structural Risk: The potential for misalignment of interests between the PE fund's general partner and its investors (including pension funds) can give rise to risks for the investors. For example, the general partner collects monitoring and transaction fees from the portfolio companies

Martin (2015).

6 See, for example, the risk parameters listed in the California Public Employees' Retirement System Investment Policy for Private Equity (PE) Program, CalPERS (2015a), https://www.calpers.ca.gov/docs/policy-private-equity-program.pdf.

7 Cohan (2015). 
owned by the PE fund; these fees enrich the general partner but reduce the price at which the companies can be sold, and in turn, the returns to the limited partners. In some cases, GPs have collected these fees from companies spiraling toward bankruptcy, exacerbating the financial crisis these companies face (Appelbaum and Batt 2016).

$>$ Valuation Risk: These risks are associated with the process that GPs use in computing the valuation of unsold companies in their funds' portfolios; the possibility exists that the valuation methodology may not be appropriate and the valuations may not be reasonable. In this case, interim calculations of the value of the portfolio may give a false impression of the actual returns investors will receive when the fund is liquidated.

Investors in private equity funds need to earn a return that compensates them for the extra risk that these investments entail. That is, these investments should provide a return equal to what the investor could have earned in the stock market plus a risk premium. To be worth undertaking, PE investments should yield a return equal to an appropriate stock market index plus 300 basis points (3 percent), according to most financial advisors.

\section{The Performance of Private Equity Funds}

The debate over whether private equity funds yield returns that outweigh the risks to investors has occurred in the context of the recognized absence of unbiased data and questions about which performance metrics should be used. Nonetheless, serious studies have been published that attempt to deal with these issues in a variety of ways. Our earlier work reviewed the evidence on PE fund performance largely prior to the financial crisis (Appelbaum and Batt 2014). In that evaluation, we examined reports provided by the private equity industry itself that, based on the internal rate of return, argued that PE buyout funds substantially outperformed the stock market. By contrast, the most credible research by top finance scholars did not rely on the internal rate of return to measure performance and reached much more modest conclusions (although most used the S\&P 500 stock market index as the point of comparison rather than the more appropriate Russell 3000 or other stock market indexes tailored to the portfolio companies in PE funds). Some of these studies showed that the median private equity fund did not beat the stock market; others showed that returns for the median fund were slightly above the market. We concluded:

"The most positive academic findings for private equity compare its performance to the S\&P 500: They report that the median fund outperforms the S\&P 500 by about 1 percent per year, and the average fund by 2-to-2.5 percent. The higher average performance is driven almost entirely by the top quartile of funds - and particularly the top decile. With the exception of the top performing funds, returns do not cover the roughly 3 percent additional return above the stock market that is required 
to compensate investors for the illiquidity of PE investments. When PE funds are compared to indices of smaller publicly traded companies whose size is comparable to most PE-owned portfolio companies (the S\&P 500 is comprised of much larger corporations), then the average PE fund barely performs better, and the median fund just matches stock market returns ....” (2014 p. 11).

In the following sections, we update that analysis to include three important new studies that rely on the public market equivalent to measure performance — some using the S\&P 500 and others a more appropriate "tailored PME," as we explain below. The findings are generally consistent with what we previously found, with top quartile PE buyout funds outperforming the S\&P 500 by a considerable margin. But the conclusions of the authors depend importantly on whether they focus on the average fund (skewed upward by better performing funds at the top) or the median fund (the typical fund), and whether they use a time horizon of 5 years or 10 years (the typical life of a fund is 10 years or longer).

The first study we review shows that at the median, and assuming the typical 10-year life span, half the funds outperformed the S\&P 500 by less than 1 percent a year ( 0.87 percent), and many of these performed even worse than this and failed to beat the S\&P 500 (Robinson and Sensoy 2011, 2015). The authors also provide important evidence that PE fund returns are highly cyclical. The second study, based on funds launched between 1984 and 2010, revealed that over this time period PE buyout funds did beat the market, but performance declined over time. The median PE fund beat the S\&P 500 by 1.75 percent annually in the 1990s and 1.5 percent annually in the 2000 s, although this is well below the 3 percent return viewed as necessary to compensate investors for the added risk associated with PE investments. Importantly, the authors found that since 2006, PE buyout funds performed about the same as the S\&P 500 (Harris, Jenkinson, and Kaplan 2015). The analysis of PitchBook data, presented below, reaches similar conclusions.

Two other new studies consider the question of persistence: is the outperformance of an initial fund repeated in a follow-on fund that is managed by the same general partner? Pension funds and other PE investors have generally assumed that they can reliably invest in a fund based on the track record of a general partner, and indeed prior research showed this to be true (Kaplan and Schoar 2005). But recent research that we review here (Harris, Jenkinson, and Kaplan 2014; Braun, Jenkinson, and Stoff 2015) reverses the earlier findings. These authors have found that more recently past performance of a general partner does not predict future performance. This raises serious doubts about whether investors should continue to rely on a GP's past record as criteria for investing in a fund. And given a lack of persistence, investors and pension funds will be hard pressed to come up with other criteria for determining which PE buyout funds are likely to yield high returns. 


\section{Recent Academic Studies of Private Equity Fund Performance}

It is widely recognized that returns to private equity buyout funds since about 2000 have not produced the outsized returns of the 1980s and 1990s when competition was scarce, hostile takeovers took Main Street companies by surprise, and many large conglomerates were ripe for dismantling. Subsequently, the remaining publicly-traded companies became leaner, the number of private equity firms rose dramatically in the 2000s, and choice targets became increasingly rare. Less clear is whether these investments are still worthwhile. The new research we review here is based in part on this new competitive environment and is therefore particularly relevant to the decisions of investors in the current period.

Private equity fund cyclicality and performance. Robinson and Sensoy (2011, 2015) examined the cyclical nature of private equity fund performance. Limited partners in a PE fund commit a certain amount of capital to the fund, but this capital is not paid in up front. Instead, the general partner calls on the LPs to provide cash to the private equity fund as attractive investment opportunities arise. Robinson and Sensoy analyzed the relationship between PE fund returns and the economic conditions that prevailed when the capital committed by limited partners was called on for actual investments. Their main question is whether PE fund returns vary depending on when in the business cycle the investment occurs. Using a proprietary database of quarterly cash flows for 837 buyout and venture capital funds from 1984 to 2010, they found — as others have found — that funds raised when the economy is heating up tend to perform worse than those raised when economic conditions are poor.

They argue that it is particularly difficult for LPs to provide cash to the PE fund during periods of recession or financial turmoil. As a result, those investors that do provide capital calls during economic downturns should earn a liquidity premium - as compensation for the greater opportunity cost of providing capital for illiquid PE investments during recessions. Their empirical results support this argument. Robinson and Sensoy found that funds that call capital in bad economic times have higher returns and distributions to investors than other funds - a result that is consistent with a liquidity premium for supplying capital under difficult conditions.

More importantly, the authors assess whether PE buyout funds actually outperform the stock market or a public market equivalent index. To measure fund performance, they did not use the internal rate of return because, as they observe, "it is a purely absolute measure of performance that makes ... no attempt to account for the opportunity cost of private equity investments" (2015 p. 6). For this reason, they follow the lead of many academic researchers and use the public market equivalent to measure performance using both the S\&P 500 and a "tailored PME," which is computed the same way as the standard PME but with alternative benchmark indexes. The tailored 
PME takes into account whether the fund is self-described as a small-cap, mid-cap, or large-cap buyout fund, using an index known as the "Fama-French size tercile index."

Robinson and Sensoy's summary statistics on fund performance are shown in Table 1. It includes a total of 542 private equity buyout funds: 174 active funds (those launched in recent years that have not been liquidated) and 368 liquidated funds (funds with a vintage year of 2005 or earlier that were effectively liquidated by the end of the sample period, June 30, 2010).

\section{TABLE 1}

\begin{tabular}{|c|c|c|c|c|}
\hline & \multicolumn{2}{|c|}{ S\&P 500 PME } & \multicolumn{2}{|c|}{ Tailored PME } \\
\hline & All Funds & Liquidated Funds & All Funds & Liquidated Funds \\
\hline Average & 1.19 & 1.18 & 1.08 & 1.10 \\
\hline Median & 1.09 & 1.09 & 0.96 & 1.00 \\
\hline 25 $5^{\text {th }}$ Percentile & 0.82 & 0.82 & 0.74 & 0.77 \\
\hline
\end{tabular}

Source: Robinson and Sensoy (2015 p. 31), Table 2.

The data represent performance over the life of the fund - typically a 10-year period — although this can be extended by mutual agreement between the GP and the limited partners. A PME of 1.09 for the median liquidated fund means that the typical PE fund outperformed the S\&P 500 by 9 percent over the life of the fund. We used the data in this table to compute average annual returns to the fund, assuming a 10-year life span. Based on this assumption, an outperformance of 1.09 for the median fund translates into an average annual outperformance of less than 1 percent ( 0.87 percent). Many funds failed to beat the S\&P 500 at all. Indeed, the bottom quarter of funds underperformed the S\&P 500 by 18 percent over the fund's life, or an annual average underperformance of nearly 2 percent (1.96 percent). When returns to PE buyout funds are computed using the "tailored PME," which includes companies more comparable in size to PE fund portfolio companies, performance is even worse: the performance of the median buyout fund just matches this stock market index and half the funds underperform it.

The top performing funds - those in the top quartile of PE fund performance - outperformed the S\&P 500 by a substantial margin - 46 percent over the 10 -year life of the fund. That translates into an annual average outperformance of nearly 4 percent (3.86 percent). Thus the top quartile funds in this data set did deliver returns that make investing in private equity attractive.

Of course, most investors will not be in top quartile funds, although this is the goal of every pension fund and others that invest in private equity. Investors look at a GP's track record, and use past performance as a guide to future investing in private equity. But this may no longer be an effective strategy. As we show in the next section, in the period prior to 2001, a successful GP with a top 
quartile fund had a high likelihood that the next fund would also be top quartile. But this type of persistence in performance disappeared for funds launched after 2000.

In their paper, Robinson and Sensoy computed annual returns on investments in PE buyout funds in a different way - based on a 5-year "holding period" rather than the 10-year life span of the funds. It is unclear from the paper why they chose this method. Recall that the PME is designed to show cumulative earnings by the PE fund relative to a stock market index over the life of the fund. Thus it is appropriate to use the typical 10-year life span of a PE fund to compute average annual returns (Kaplan and Schoar 2005; Phalippou and Gottschalg 2009).

In their estimate of returns over five years, Robinson and Sensoy also used the average S\&P 500 PME rather than the median PME. The average PME is pulled up by the outstanding performance of top quartile funds. The average S\&P $500 \mathrm{PME}$ in this data set is 1.18 or a cumulative outperformance of 18 percent over the life of the fund. Using the average performance for funds in the sample and a holding period of 5 years, the authors report higher returns to PE funds than what we calculated a return of about 3 percent a year. They conclude that, “... the average buyout fund in our sample has outperformed the S\&P 500 by 18 percent over the life of the fund, or about 3 percent per year at an investment holding period of about five years" (2015 p. 10).

While the average return may be a useful figure for a very large pension fund or other institutional investor able to invest in a wide variety of PE buyout funds, it is not particularly relevant for the typical PE investor who invests in one or a few funds and is better served by knowing what the median return is. Moreover, the authors do not explain why investors in the fund would be interested in performance over a 5-year average holding period for portfolio companies. We note that holding periods for portfolio companies have gotten longer since the Great Recession. GPs are asking investors for extensions of a fund's life span beyond the agreed upon 10 years to allow additional time for the GP to dispose of unrealized assets and avoid forced sales on unfavorable terms.

Research firm Preqin Ltd. estimates that funds launched in 2005 and earlier held about $\$ 115$ billion in unrealized assets at the end of $2014 .^{8}$ Any extension in the life of a fund reduces its average annual returns. What matters for LPs is the cumulative return on the capital they committed over the 10 or more years during which the GP controls capital calls and distributions. In our view, it makes more sense from the perspective of investors in PE buyout funds to calculate average annual returns

$8 \operatorname{Lim}(2016)$. 
based on the PME and the life span of the fund. For the sample of funds in Robinson and Sensoy, and assuming a life span of 10 years, that figure would be 1.7 percent (rather than 3 percent) a year.

The performance of public and private equity compared. The second recent study of private equity fund returns compares the performance of public and private equity (Harris, Jenkinson, and Kaplan 2015). The authors used cash flow data from the holdings of almost 300 LPs that invested in 781 North American PE buyout funds plus data from 300 European buyout funds. Approximately 40 percent of the LPs in the data set are pension funds. The data include PE buyout funds launched between 1984 and 2010; and the data end in June, 2014. Thus, the authors were able to examine PE performance over a period that includes the economic boom of 2003 through 2007, the financial crisis of 2008-2009, and the post-crisis recovery to 2014. They estimated average returns net of fees and profit shares (carried interest). In addition to comparing the performance of private equity and public equity, they also assessed the role that investment in top quartile funds plays in LP investment results.

Like Robinson and Sensoy, the authors did not use the IRR to measure performance, as it does not provide, "...a direct way to assess how PE returns compare to those to public equity. We focus on Kaplan and Schoar's (2005) PME, which directly compares an investment in a PE fund to an equivalently timed investment in the relevant public market” (2015 p. 6).

The results of the analysis over the full time period were positive. The authors reported that, compared to the S\&P 500, average and median PE fund performance for the entire period is positive:

"The weighted-average, average, and median PMEs also exceed 1.0 in all three decades. The weighted average buyout PME exceeds 1.0 for 25 of the 27 vintages from 1984 to 2010; the average for 23 and even the median PME exceeds 1.0 for 19 of 27 vintages. And, ignoring vintage years, the average fund in the entire sample has an average PME of 1.18 and a median PME of 1.09...”(2015 p. 9)

They go on to show, however, that performance declined over time: "[b]uyout fund returns have exceeded those from public markets in almost all vintage years before 2006. Since 2006, buyout fund performance has been roughly equal to those of public markets" (2015 p. 2).

Tables 2 and $\mathbf{3}$ below are extracts from tables II and IV in the Harris, Jenkinson, and Kaplan study. Table 2 reports the average, median, and weighted average PMEs as of June 2014 for funds of different vintages compared to equivalent-timed investments in the S\&P 500. Weighted averages use 
the capital committed to the funds as weights. Table 3 reports PMEs by performance quartile. In each vintage year, a fund is assigned to a quartile based on its PME relative to others in that year. Figures reported are the average PME across funds in that quartile.

In considering fund performance, most investors are interested in typical (median) performance because they are likely to be invested in a fund that performs at or around the median and have a 50 percent chance of doing worse than the median fund. Table 2 shows that the typical fund launched in the 1990s outperformed the S\&P 500 by a cumulative 16 percent over the life of the fund, and by 19 percent for funds launched in the 2000s. The 16 percent median outperformance for the 1990s implies an average annual outperformance of 1.5 percent, relative to the S\&P 500; the 19 percent median outperformance of funds in the 2000s implies an average annual outperformance of 1.75 percent. Both are well below the three percent return that most investors in private equity view as a reasonable premium for the added risk associated with these investments. An investor in a fund with average returns in either decade would experience an average annual outperformance of 2.1 percent - better, but still below the widely used "stock market plus three percent" benchmark. Funds launched in 2005 outperformed the S\&P 500 by 12 percent over the period from 2005 to 2014. The performance of PE funds launched since 2006, however, has approximately matched the performance of the S\&P 500 from their date of launch to 2014.

TABLE 2

\begin{tabular}{|c|c|c|c|}
\hline \multicolumn{4}{|c|}{ Buyout Funds, S\&P 500 Public Market Equivalent (PME) } \\
\hline Vintage Year & Average & Median & Weighted Average \\
\hline Average 1990s & 1.23 & 1.16 & 1.25 \\
\hline Average 2000s & 1.23 & 1.19 & 1.28 \\
\hline 2005 & 1.26 & 1.12 & 1.26 \\
\hline 2006 & 1.01 & 1.03 & 1.02 \\
\hline 2007 & 1.01 & 0.97 & 0.99 \\
\hline 2008 & 0.97 & 0.96 & 1.03 \\
\hline 2009 & 0.96 & 0.92 & 1.01 \\
\hline
\end{tabular}

Source: Harris, Jenkinson, and Kaplan (2015 p. 30), Table II.

As we noted earlier, investors in PE funds are interested in the cumulative earnings on capital they have committed over the life span of the fund - typically 10 years. The 19 percent median outperformance of funds in the 1990s, relative to the S\&P 500, implies an average annual outperformance of 1.75 percent; the 16 percent median outperformance for the 2000 s implies an average annual outperformance of 1.5 percent. This is well below the 3 percent return that most investors in private equity view as a reasonable premium for the added risk associated with these investments. An investor in a fund with average returns in either decade would experience an average 
annual outperformance of 2.1 percent — better, but still below the widely used "stock market plus 3 percent" benchmark.

As we see in Table 3, top quartile funds did yield PME values that placed their cumulative returns far above the S\&P 500 for all funds launched between 1994 and 1999, with the average annual return corresponding to a PME of 1.91 equal to 6.7 percent. Even second quartile funds in those vintage years (PME of 1.32) provided an average annual return that exceeded the S\&P 500 by 2.8 percent. Even in the 1990s, however, funds in the third and fourth quartiles underperformed the S\&P 500.

Fund performance over the 2000s was below that of the 1990s, but the average over the decade still looks strong: the PME of 1.73 for top quartile funds translates to an annual outperformance of 5.6 percent; the PME of 1.27 for second quartile funds implies an annual outperformance of 2.5 percent. However, these averages for the decade mask a dramatic decline in performance for funds launched after 2005. While not as strong as in the earlier period, top quartile funds continued to perform well. Top quartile funds in the 2007 vintage, for example, beat the S\&P 500 by an estimated 3.5 percent a year and those launched in 2010 beat it by 1.75 percent a year. For vintages after 2005, however, funds not in the top quartile performed poorly relative to this stock market index.

TABLE 3

\begin{tabular}{|lcccc|}
\hline Vintage Year & $\begin{array}{c}\text { Buyout Funds, S\&P 500 Public Market Equivalent (PME) } \\
\text { Bottom (4th) } \\
\text { Quartile }\end{array}$ & 3rd Quartile & 2nd Quartile & $\begin{array}{c}\text { Top (1st) } \\
\text { Quartile }\end{array}$ \\
Average 1990s & 0.54 & 0.94 & 1.32 & 1.91 \\
Average 2000s & 0.73 & 1.05 & 1.27 & 1.73 \\
& & & & \\
2005 & 0.77 & 1.04 & 1.29 & 1.89 \\
2006 & 0.61 & 0.95 & 1.10 & 1.39 \\
2007 & 0.66 & 0.92 & 1.05 & 1.41 \\
2008 & 0.69 & 0.89 & 1.03 & 1.28 \\
2009 & 0.72 & 0.88 & 0.97 & 1.23 \\
2010 & 0.63 & 0.84 & 0.95 & 1.19 \\
\hline
\end{tabular}

Source: Harris, Jenkinson, and Kaplan (2015 p. 33), Table II.

Like Robinson and Sensoy, Harris, Jenkinson, and Kaplan did not calculate average annual returns to investments in PE based on Kaplan and Schoar's public market equivalent metric. Instead, they computed annual returns using a different methodology (Gredit, Griffiths, and Stucke 2014). The average PME across the 781 funds in their sample is 1.20 (Table II), or a cumulative outperformance of 20 percent. If we assume that funds have a 10-year life span, then the annual average outperformance is 1.8 percent. Using their alternative methodology, however, Harris, Jenkinson and Kaplan find an annual outperformance of 3.07 percent for the average fund and an outperformance of 2.40 percent for the median fund. As Harris, Jenkinson, and Kaplan explained these results, "The 
average PME of about 1.20 and an average annual excess return of roughly 3 to 4 percent suggest that the typical duration of a buyout fund is on the order of five years, a duration lower than the typical fund's legal life of 10 to 13 years (2015 p. 10)." That is, to reconcile a 20 percent out performance over the life of the fund (which implies an average annual outperformance of 1.8 percent over the typical 10-year life of a fund) with a 3 to 4 percent annual return requires that the return was actually earned over a five-year period.

This 5-year period is labeled, by analogy with investments in bonds, as the "duration" of the fund. But the analogy to investments in bonds is spurious. A bond is an instrument that pays interest and principal on pre-specified dates. Investors can calculate the duration for a bond because they know what the cash flows will be and the date at which they will be paid. This is clearly not the case for investments in private equity funds where both the amount and timing of capital calls and distributions are uncertain. As we observed earlier, investors are obligated to pay 100 percent of the capital they have committed, but the cash flows - both capital calls and distributions — are decided by the general partner. Investors in private equity must manage their liquidity to accommodate capital calls by the GP. And GPs have the option of paying out distributions whenever they want to.

For pension funds and other investors in PE, the bottom line concern is how much extra money they can make over the life span of the fund compared to investing in the stock market. This is what the PME is designed to measure. As noted above, it is becoming more common today for GPs to request an extension beyond the agreed upon 10 years. The $W$ all Street Journal recently reported, for example, that 2005 vintage Carlyle Partners IV received investor approval for a two-year extension to allow more time to exit two remaining investments. ${ }^{10}$

Building Stock Market Indexes Tailored to the Characteristics of PE Buyout Funds. A more recent study develops a much finer-grained approach to creating a stock market index of companies that more closely match the characteristics of PE portfolio companies (L'Her, Stoyanova, Shaw, Scott, and Lai 2016). The authors build on earlier research, including the studies by Robinson and Sensoy (2015) and Harris and colleagues (2015) discussed above. They begin by replicating prior approaches calculating the risk-adjusted performance results of PE buyout funds when they are compared to the public market equivalent (PME) based on the S\&P 500 index. Their results are in line with those of the earlier studies. They find a similar level of outperformance by PE buyout funds for pre-2006 vintages, while post-2005 vintages just match the performance of the S\&P 500.

9 The duration of a bond is the point in time at which the amount paid for the bond and the cash flow received from the bond are equal.

$10 \operatorname{Lim}(2016)$. 
L'Her and colleagues then go on to develop stock market indexes of publicly-traded companies more closely tailored to the characteristics (i.e. firm size, sector, and leverage) of companies acquired by the PE buyout funds in their sample. They construct PME measures based on these stock market indexes. Using these more carefully tailored measures of performance, they find that the average returns of vintages of buyout funds post-2005 fail to outperform the market. PE fund performance relative to a stock market index grows worse as the companies in the index more closely resemble those in the PE buyout funds. Indeed, average returns over the full array of PE buyout funds in the 1986 to 2008 vintages fail to beat the tailored stock market indexes. Rather, their performance approximately matches the performance of these indexes.

The study by L'Her and colleagues included more years of data and a larger sample of PE buyout funds than the study by Harris, Jenkinson and Kaplan. In the early years of a buyout fund, GPs are calling capital commitments from their LP investors and buying companies for the fund's portfolio. There are few to no returns to speak of. In the later years (years six to ten), the funds are typically selling the companies acquired earlier and providing investors with returns. The longer time period in the L'Her et al. study provides a greater opportunity for more recent vintages to exit investments and record returns. Thus the authors argue that it might be reasonable to expect to find that the 2005-2008 vintages in this study show higher returns than was the case for these vintages in Harris et al. (2015). But, as L'Her and colleagues report, that was not the case. Even with their larger sample and longer time period, the later vintages of funds in their sample fared no better than in Harris et al. This, as they note, provides further evidence for the view that, on average, PE buyout funds have not outperformed their risk-adjusted stock market indexes. The authors conclude, "After adjusting for appropriate risks, we found no outperformance of buyout funds vis-à-vis their public market equivalents on a dollar-weighted basis" (L'Her et al. 2016 p. 10). This finding is based on average, not median, performance of $\mathrm{PE}$ buyout funds when compared to appropriate stock market indexes. As we saw earlier, median fund performance is generally worse than average performance. Importantly, this finding suggests that even large pension funds and institutional investors that invest in a large number of PE buyout funds are unlikely, on average, to see investments in recently launched funds outperform the stock market.

Average and median returns for vintages since 2000 have been disappointing, especially for vintages after 2005, which have only slightly exceeded the S\&P 500 and barely matched or actually underperformed stock market indexes more closely tailored to match companies in PE fund portfolios. However top quartile funds have been stellar performers in that they have outperformed the S\&P 500 by a very wide margin. Pension funds or other PE investors in those funds can be confident of high returns. The question is whether limited partners can be confident that they will 
earn high returns in the future by identifying GPs that have a "hot hand." In the next section, we examine this issue of "persistence" — whether follow-on funds of GPs with top-quartile funds do in fact perform as well as their predecessors.

\section{How Persistent Is the Performance of PE Buyout Funds?}

The question of persistence - the relationship between the final performance of an initial fund and a subsequent fund managed by the same general partner — is critical to PE investors. They need criteria for deciding which PE fund to invest in, and often they have relied on the prior performance record of a general partner. Research on this question was most convincingly answered in a widelycited paper by Kaplan and Schoar (2005), who analyzed the performance of U.S. venture capital and PE buyout funds with vintage years up to the late 1990s. They examined the performance of mature funds in which all (or nearly all) investments in portfolio companies had been exited. Ranking funds based on their performance using the public market equivalent, they divided the initial funds into terciles - the top third of performers, the middle third of performers, and bottom third of performers. They then analyzed the likelihood that the subsequent fund managed by the same GP would be in the top, middle, or bottom tercile. Their results are summarized in Table 4.

TABLE 4

\begin{tabular}{|ccccc|}
\hline & \multicolumn{4}{c|}{ Buyout Funds, S\&P 500 Public Market Equivalent (percent) } \\
\hline & & \multicolumn{3}{c|}{ Follow-on Fund Tercile } \\
Previous & Top Tercile & Top Tercile & Middle Tercile & Bottom Tercile \\
Fund & Middle Tercile & 48 & 31 & 21 \\
Tercile & Bottom Tercile & 32 & 38 & 30 \\
& & 20 & 31 & 49 \\
\hline
\end{tabular}

Source: Kaplan and Schoar (2005).

These results show strong persistence of performance. In this sample of funds, GPs with funds in the top tercile have a much higher than one-third likelihood (48 percent compared with 33 percent) that their subsequent fund will also be in the top tercile. Similarly, GPs with funds in the bottom tercile have a much higher than one-third likelihood (49 percent) that their subsequent fund will be in the bottom tercile.

Based on these findings for funds launched prior to 2000, pension funds and other investors in private equity could conclude that investing with the "right" general partner — one whose previous fund had performed well — would yield high returns. This view continues to be held today — it is common for investment staff to assure pension fund trustees that their investments in private equity will outperform the stock market because their investments are with top performing GPs. The conventional wisdom is that private equity investment is an exception to the adage that past investment performance is no guarantee of future earnings. 
Unfortunately, more recent research has found that the persistence of performance by general partners has declined as the private equity industry has matured. Two recent studies show that today, past performance of a fund managed by a particular GP is no longer a good predictor of how that GP will perform in the future. Using data that is net of all fees and carried interest, Harris, Jenkinson, and Kaplan (2014) assessed the persistence of buyout fund performance of the same general partners across current and prior funds. They analyzed persistence for funds launched before 2001 and for those launched after 2000. They confirmed the earlier findings of strong persistence of performance for pre-2001 funds. For the post-2000 period, however, they did not find evidence of persistence except among the lowest performing GPs. The authors sorted PE funds by the quartile of their previous fund, as measured by the public market equivalent (PME), and then the likelihood that their subsequent fund would be in each quartile. Their results are summarized in Table 5, where 1 is top quartile, 2 is second quartile, 3 is third quartile, and 4 is bottom quartile.

TABLE 5

\begin{tabular}{|clcccc|}
\hline \multicolumn{5}{|c|}{ Persistence of Private Equity Fund GP Performance, post-2000 (percent) } \\
\hline & & \multicolumn{4}{c|}{ Follow-on Fund Quartile } \\
Previous & 1 (top) & 1 (top) & 2 & 3 & 4 (bottom) \\
Fund & 2 & 22 & 29 & 30 & 19 \\
Quartile & 3 & 15 & 23 & 32 & 21 \\
& 4 (bottom) & 21 & 28 & 39 & 18 \\
& & & 14 & 32 & 32 \\
\hline
\end{tabular}

Source: Harris, Jenkinson, and Kaplan (2014).

Based on this analysis, GPs with a top performing fund in the post-2000 period had a 22 percent probability that their subsequent fund would be top performing. A GP with a bottom performing fund had a 21 percent probability the subsequent fund would be top performing — not much different from that of a top performing GP. In other words, the probability is essentially random and indicates that past top performance is no longer a guide to future performance. While it is not possible to predict which GPs will have subsequent funds that are top performers, there is a tendency for poor performance to persist. A GP with a fund in the lowest quartile has a 64 percent chance that a subsequent fund will be below the median.

A second study using different data reached similar conclusions (Braun, Jenkinson, and Stoff 2015). This study used a sample of buyout fund deals that included both early and more recent funds; and they analyzed gross returns - before fees and profit shares (carried interest) have been subtracted. Their sample of deals is roughly split between the U.S. and Europe and covers the period 1974 to 2012. The authors considered only buyout funds in which investments in all or most (more than 50 percent) of the portfolio companies had been exited. They partitioned their sample into an early period (through the end of 2000), and a later period, from 2001 forward. 
Analyzing realized deals, they found that the persistence of GP performance has declined substantially as the PE industry has matured and competition has increased. They found a strong effect of the GP on performance in the pre-2001 period, but not in the post-2000 period. They reported that, "... deal-level analyses found that performance persistence has largely disappeared in recent years" (2015 p. 6). While their regression analyses of the persistence of deal performance examined the earlier and later periods separately, the table that reports the likelihood that a top performing fund will be followed by another top performing fund covers the full time period. Thus, we cannot separately observe the likelihood of persistence in the post-2000 sample of funds (see Table 6).

Nevertheless, it is possible to observe the decline in the persistence of performance at the fund level as compared to the earlier Kaplan and Schoar analysis. While differences in the data sets used in the two papers - in terms of region, years, and number and type of funds - can account for some of this difference, the authors conclude that " ...[o]verall, the evidence we present suggests that performance persistence has largely disappeared as the PE market has matured and become more competitive" (2015 p. 7). In summarizing their results as compared to those of Kaplan and Schoar, they concluded, "We find that the probability of repeating top (bottom) tercile performance is lower in our sample: 39 percent (40 percent), and we can only reject the hypothesis of random transition probabilities at the 10 percent level" (2015 p. 13). That is, even considering the full sample of funds, including the early period in which performance was persistent, the likelihood that a top tercile fund will be succeeded by a top tercile fund may not be better than chance.

TABLE 6

\begin{tabular}{|c|c|c|c|c|}
\hline \multirow[b]{3}{*}{ Previous } & & \multicolumn{3}{|c|}{ Follow-on Fund Tercile } \\
\hline & & Top Tercile & Middle Tercile & Bottom Tercile \\
\hline & Top Tercile & 39 & 30 & 31 \\
\hline Fund & Middle Tercile & 29 & 37 & 34 \\
\hline Tercile & Bottom Tercile & 26 & 34 & 30 \\
\hline
\end{tabular}

Source: Braun, Jenkinson, and Stoff (2015).

Pension funds, endowments, and other investors in private equity have long relied on a belief in the persistence of returns when choosing which GPs to invest with. But recent research has found little or no persistence in the performance of fund managers. The conclusion to be drawn from these studies is that past performance cannot be used to predict the future. Braun, Jenkinson, and Stoff conclude that their research has uncomfortable implications for private equity investors — sticking with top-performing managers is no longer a recipe for success. 


\section{PE Fund Performance over Time Using the PME and IRR}

The performance of private equity funds over time has also been tracked by PitchBook, an investment research and data base firm that tracks private equity and venture capital firms, their funds, limited partners, and portfolio companies. A 2015 PitchBook Benchmarking and Fund Performance Report provides an analysis of annual private equity fund performance between 2002 and 2012, comparing results using the public market equivalent measure and the internal rate of return (PitchBook 2015b). The results mirror those of Harris, Jenkinson, and Kaplan (2015), discussed above.

The PitchBook report notes that one of the main drawbacks of using IRRs “... is that they cannot be directly compared to indices that are used in mainstream asset classes. Public market equivalent benchmarks effectively address this problem, making it possible to directly compare alternative asset fund performance to the performance of indexed asset classes by using fund-level cash flows" (2015b p. 5). PitchBook uses the PME benchmark developed by Kaplan and Schoar (2005) to compare private equity fund performance to the Russell 3000. Many view the Russell 3000 as a more appropriate benchmark index for PE buyout funds than the S\&P 500 because the Russell 3000 is based on smaller companies that are more similar to the companies found in PE fund portfolios. Figure 1, from the 2015 PitchBook Report, compares the performance of the typical (median) fund, from the year of its inception to September 30, 2015, with that of the Russell 3000.

The 1.3 value of the PME for the typical PE fund launched in 2004 indicates an outperformance of 30 percent since the fund's inception 11 years earlier, or an average annual outperformance of 2.41 percent. The typical fund launched a year later, in 2005, with a PME value of $1.13^{11}$ beat the Russell 3000 index by a cumulative 13 percent over the 10 years since the fund's inception. This implies an average annual outperformance of just 1.14 percent. This is a far cry from the performance of the typical PE fund in 2001 (not shown in the figure), when the PME value since inception was over 1.60 - a 60 percent outperformance - and the average annual outperformance over 10 years ${ }^{12}$ was 4.81 percent. The PME of 0.9 for the typical fund launched in 2009 means that the fund underperformed the Russell 3000 index by 10 percent over the six years since inception - an average annual underperformance of 1.74 percent.

1 This is the same value for the median PME in 2005 as reported in Harris, Jenkinson and Kaplan (2015).

12 Most PE funds launched in 2001 had exited all, or nearly all, their investments by 2011. The PME performance of the typical PE fund launched in 2001 comes from the second quarter 2014 PitchBook benchmarking and fund performance report (PitchBook 2014). 
FIGURE 1

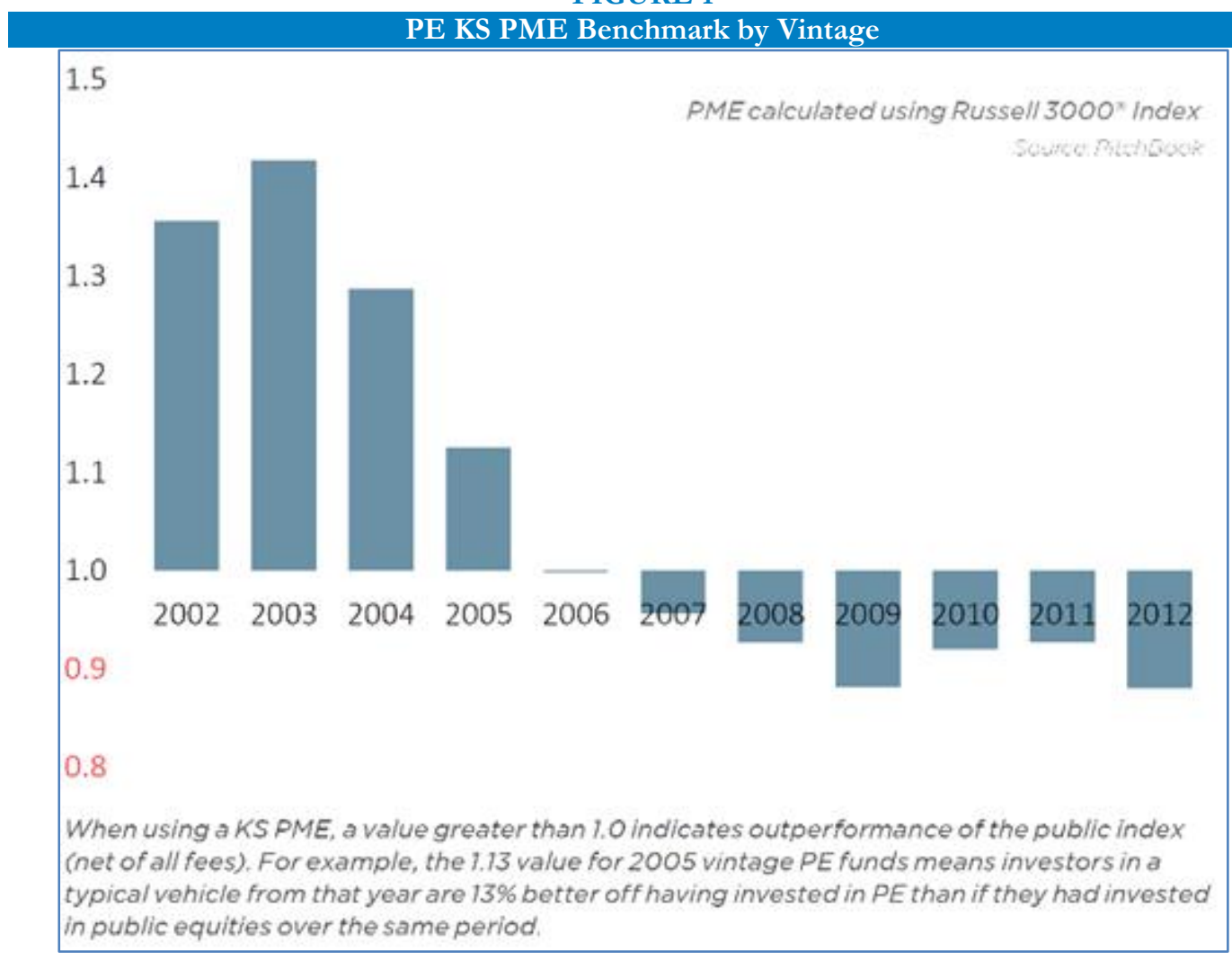

Source: PitchBook (2015 p. 5)

Despite its well-known weaknesses, the IRR has continued to be viewed as the gold standard of benchmarking by the private equity industry. Its continued popularity is due in part to the fact that it tends to exaggerate PE fund performance while the fund is active. Not until the PE fund is liquidated at the end of its 10-year life will investors actually be able to evaluate the return to their investment in the fund. We can see how much better PE fund performance looks using the internal rate of return in Table 7. Even using this metric, however, the declining performance of PE buyout funds in recent years is evident.

The median IRR for PE funds launched in 2001 was 21.5 percent according to PitchBook (2014). The typical fund launched after 2001, however, failed to deliver on the private equity industry's promise of a return of 20 percent or more. As of 2015, median returns were far below that mark and even top performing funds launched after 2003, with the exception of the 2009 and the very recent 2012 vintages, have not come close to delivering this return. While the decline in PE fund returns is apparent even using the IRR as the measure of performance, PE performance clearly looks much better using IRR rather than PME as the metric. 
TABLE 7

\begin{tabular}{|lcccccccccc|c|}
\hline \multicolumn{7}{|c|}{ Private Equity Fund Performance (IRR), 2002-2012 (percent) } \\
Vintage Year & 2002 & 2003 & 2004 & 2005 & 2006 & 2007 & 2008 & 2009 & 2010 & 2011 & 2012 \\
Top Quartile IRR Hurdle & 29.3 & 31.1 & 16.5 & 11.8 & 10.1 & 14.9 & 17.1 & 19.2 & 17.7 & 16.7 & 20.9 \\
Median IRR & 16.7 & 17.3 & 12.3 & 8.0 & 7.1 & 9.4 & 10.5 & 13.4 & 10.2 & 11.2 & 10.8 \\
Bottom Quartile IRR Hurdle & 9.3 & 10.5 & 4.6 & 2.9 & 2.5 & 6.3 & 6.3 & 9.8 & 5.6 & 6.9 & 4.0 \\
\hline
\end{tabular}

Source: PitchBook (2015 p. 8)

The median IRR reported for recent PE buyout funds may provide naïve investors who fail to risk adjust returns with the illusion that PE investments are worthwhile. But even apart from the wellknown failings of the performance measure, absolute returns from investments in private equity are an inappropriate guide to the payoff from this asset class. That is because there are many risks associated with investing in private equity. To be worthwhile, returns from investments in private equity must exceed returns from investing in public equities (the stock market) by an amount sufficient to compensate investors for these added risks.

\section{Pension Funds and Private Equity Returns}

Pension funds were early investors in private equity; since 2000, they have become much larger and more significant investors in this asset class. In recent years, public and private pension funds have contributed over a third of the capital committed to private equity funds. The California Public Employees Retirement System (CalPERS) and the California State Teachers Retirement System (CalSTRS) are regarded as leaders by other pension funds. This is due to their large size and long history of private equity investing, their significant investments in private equity, and the number of PE buyout funds in which they have invested.

These substantial commitments by pension funds to risky private equity investments reflect several factors: the changing regulatory environment that freed up pension fund managers to invest in a wider range of financial products and the increased availability of those products; low treasury bond yields; changing guidelines under the Employee Retirement Income Security Act (ERISA) that encouraged more risky investments; and the increasing demands for payouts of benefits to an aging membership.

Pension funds are based in trust law and have a fiduciary duty that is higher than that imposed on corporations (Youngdahl 2012 p. 115). The legal language that historically governed the actions of pension fund managers states that these fiduciaries must use "...the entirety of their skill, care, and diligence" when exercising their authority; and must use their discretion in deciding whether or not to delegate authority and to whom (Hawley, Johnson, and Waitzer 2011 p. 6-9; Youngdahl 2012 p. 115). This meant investing in only the safest assets, such as government bonds. This approach was 
modified and replaced by the "prudent man rule," characterized as "... how men of prudence, discretion and intelligence manage their own affairs, not in regard to speculation, but in regard to the permanent disposition of their funds...." (Youngdahl 2012 p. 122 and footnote 59). This broadened the range of permitted investments, but ruled out investments in speculative securities, purchase of securities in new enterprises, and purchase of land for resale (Youngdahl 2012 p. 122).

Recognizing these changes, the 1974 Pension Act (ERISA) set only a general standard that offered pension trustees latitude to use their best "reasonable" judgment in the allocation of pension assets in a broad range of investment vehicles, including the stock market, speculative securities, and junk bonds (Hawley et al. 2011 p. 6). Economists, however, argued that "reasonable" should be interpreted in terms of "rational," individual self-interested behavior (Lydenberg 2012 p. 3-5). Rational economic investment behavior was defined in terms of Modern Portfolio Theory (MPT), which assumes that markets are efficient, information is symmetric and able to correct temporary market imbalances, investors are risk averse, and risks can be minimized through diversification, securitization, and hedging (Lydenberg 2012). In addition, rule changes by the Department of Labor in 1978 allowed this standard to be met by assessing risks at the portfolio-wide basis rather than an investment-by-investment basis.

In the face of these changes and financial innovations that offered a broader array of investment vehicles with potentially higher rates of return, the prior 'prudent man' standard collapsed. Modern Portfolio Theory became the dominant approach for allocating pension fund assets and encouraged pension fund managers to invest in riskier individual financial products. In 1992, the assumptions of Modern Portfolio Theory were incorporated into trust law by replacing the language of the "prudent man rule" with the "prudent investor rule." The duty of loyalty became defined narrowly in terms of a fiduciary's duty to assess risk and return and diversify investments to limit losses (Youngdahl 2012 p. 123). This was later reaffirmed and applied to investments in a wide range of risky products and for delegation of responsibilities to expert service providers (Hawley, Johnson, and Waitzer 2011 p. 7).

Arguably, pension funds are under greater pressure than ever to enhance returns after the losses suffered during the 2008 economic crisis and to cover current retirement outlays without increasing beneficiary or taxpayer contributions. Many pension fund trustees and managers remain convinced of the soundness of Modern Portfolio Theory — that as long as risk is diversified across a large portfolio of investments, their risk exposure is sufficiently minimized. And, to the extent that private equity investments do beat the market, the "prudent investor" rule can be interpreted as requiring fund managers to continue to invest in these funds. That rule requires, however, that pension funds evaluate the returns from investing in private equity relative to the risks. 
The legal understanding of fiduciary duty underwent large changes in the last half of the $20^{\text {th }}$ century, narrowing the duty of loyalty and permitting pension funds to delegate decision making to advisors and to make risky investments. What remains of fiduciary duty, however, is that pension trustees must carefully weigh risks against returns when investing.

The requirement that investment returns should be commensurate with risk means that absolute returns are not an appropriate measure for trustees to use in evaluating returns from private equity investments. An absolute return strategy simply seeks positive returns and is not evaluated in relation to alternative, less risky investments. The investment portfolio appropriate for such a strategy is not intended to outperform stocks and bonds when returns to these investments are positive. ${ }^{13}$ The lack of a benchmark means there is no weighing of returns against the risks of the investment. That is because the basic premise of an absolute return approach is simply its ability to preserve capital — not to earn returns commensurate with risk. Investment advisors who adopt an absolute return approach invest flexibly and diversify investments across asset classes; the successful ones are those who demonstrate skill in asset allocation. ${ }^{14}$ This is clearly not an option for private equity buyout funds. Thus, private equity fund investments lack the characteristics required for an absolute return strategy.

Pension fund staff may find that eliminating the benchmark that is used to risk-adjust returns from risky investments is attractive as it lets them claim success in investing workers' retirement savings as long as these investments earn a positive return. In late 2015, the Board of Trustees of CalPERS debated this kind of measure. CalPERS staff brought forth a proposal at the pension fund's December 2015 board meeting to eliminate the requirement that its PE program's “strategic objective is to maximize risk-adjusted rates of return" (CalPERS 2015a p. 1). Had it passed, CalPERS would have substituted an inappropriate absolute returns standard, and returns from private equity investments would no longer be risk adjusted. Fortunately, the CalPERS board rejected this change.

Private equity is sold to pension fund trustees as a way to achieve high returns that outperform the stock market. In a recent report we noted that PE firms charge high fees directly to investors and indirectly via the monitoring fees that portfolio companies are often required to pay (Appelbaum and Batt 2016). The rationale for these very high management, performance, and monitoring fees is precisely this promise of returns substantially above stock market returns. Indeed, as noted earlier, higher return is necessary in order to compensate pension funds for the greater risk involved in

13 Putnam Investments (2016).

14 Maton (2010). 
these investments. To be worthwhile undertaking, the return from PE investments should equal stock market returns plus a risk premium typically equal to 300 basis points ( 3 percent). This is the "benchmark" that limited partners that invest in private equity expect to meet or beat.

\section{Benchmarking Private Equity Returns}

Pension funds use a variety of approaches for benchmarking private equity performance. Few if any, however, use the PME that is preferred by finance experts who study the issue. Instead, the typical approach taken by pension funds is to use the IRR, despite its weaknesses, and benchmark the performance of PE investments against an appropriate stock market index plus 300 basis points (3 percent) to adjust for the greater risk inherent in investment in private equity. For example, public employee pension funds in Oregon and Washington - the Oregon Public Employees Retirement Fund (OPERF) and the Washington State Investment Board which manages a number of public employee pension funds in a Commingled Trust Fund (CTF) - benchmark the IRR measure of their private equity returns against the Russell 3000 plus 3 percent. This is a benchmark widely used by pension funds.

The California Public Employees Retirement System (CalPERS), whose portfolio of publicly traded stocks includes a large proportion of foreign stocks, uses a stock market index for its private equity investments that reflects that choice. Its benchmark is, appropriately, a stock market index comprised of two-thirds domestic stocks (two-thirds times the FTSE U.S. Total Market Index) and one-third foreign stocks (one-third times the FTSE All World Total Market Index ex U.S.) plus 300 basis points ( 3 percent). While not as accurate as using the PME to evaluate the performance of PE investments, these metrics do include an adjustment for the greater riskiness of these investments.

Surprisingly, however, some major public pension funds have as their strategic objective that their private equity investments simply yield a return above the median return of PE buyout funds. The California State Teachers Retirement System (CalSTRS) and the Teachers Retirement System of the City of New York (TSR), for example, both use the State Street Private Equity Index as their benchmark. The Pennsylvania State Education Retirement System (PSERS) uses the Burgiss median PE fund as its benchmark. The New York State and Local Retirement System (NYSLRS) uses the Cambridge US PE index. These benchmarks vary widely. The benchmarks for evaluating performance over the 10-year period ending in June 2015 range from 4.9 percent for the Burgiss median to 9 or 10 percent using the State Street Private Equity Index to 13.6 percent for the Cambridge US PE index. The wide range of values for this type of benchmark raises questions about exactly what is captured by these indexes. 
More fundamentally, however, measures that benchmark a particular fund against the average performance of a sample of funds do not compare PE returns with what could have been earned had the funds been invested in a different asset class. Economists call this "opportunity cost" and argue that to understand the true cost of a decision (including the decision to invest in private equity), an investor must consider what is lost by not pursuing the next best alternative. This, in fact, is what occurs when private equity returns are compared to returns from the stock market plus a risk premium. Pension funds are making decisions about whether to make equity investments via private equity funds or via their next best alternative — public equities that trade on stock markets. The decision to invest in private equity rather than public equities is a good decision if the returns from $\mathrm{PE}$ investments exceed those from investments in the stock market by a sufficient margin to compensate for added risk.

We can illustrate the secular decline in PE returns over the past 10 years by looking at CalPERS's private equity performance. In 2012, CalPERS began tracking PE returns separately from other alternative investments and adopted its current, risk-adjusted benchmark for PE performance. Thus, we have consistent results for CalPERS PE performance beginning in June 2012.

Table 8 and Figure 2 report CalPERS average annual returns from its PE investments for 10-year periods ending in June of the year indicated. Data are extracted from the pension fund's Comprehensive Annual Financial Reports (CAFR) (CalPERS 2015b). In June 2012, CalPERS 10year average annual PE returns beat the benchmark by 1.5 percent. That is, it outperformed its stock market index by 4.5 percent $(3+1.5)$. The 10 years preceding June 2012 would have included many funds from the 2002, 2003, 2004, and 2005 vintages. As we saw earlier, the typical fund in these vintages outperformed the stock market. Average annual returns for the 10 -year period ending in June 2013 just exceeded the benchmark; investments in PE outperformed CalPERS's stock market index by 3.2 percent. By June 2014, when most PE funds launched in 2002 and 2003 had been liquidated and were no longer included in the calculation of 10-year returns, CalPERS's private equity returns slipped below the benchmark by 210 basis points (2.1 percent). Annual PE returns beat the stock market on average over the 10-year period ending in June 2014, but by only 0.9 percent - not enough to justify investing in private rather than in public equities. In the most recent 10-year period, returns from CalPERS PE investments just matched the performance of its stock market index and provided no premium for the added risk inherent in these investments (CalPERS 2015b). 
TABLE 8

\begin{tabular}{|lcccc|}
\hline \multicolumn{5}{r}{ CalPERS Average Annual Returns for 10-Year Periods, } \\
\hline & June 2012-2015 (percent) \\
CalPERS PE & 9.8 & June 2013 & June 2014 & June 2015 \\
Benchmark & 8.3 & 12.3 & 13.3 & 11.9 \\
\hline
\end{tabular}

Source: CAFR filings. Benchmark $=67 \%$ FTSE USTMI $+33 \%$ FTSEAWEXUS $+3 \%$.

FIGURE 2

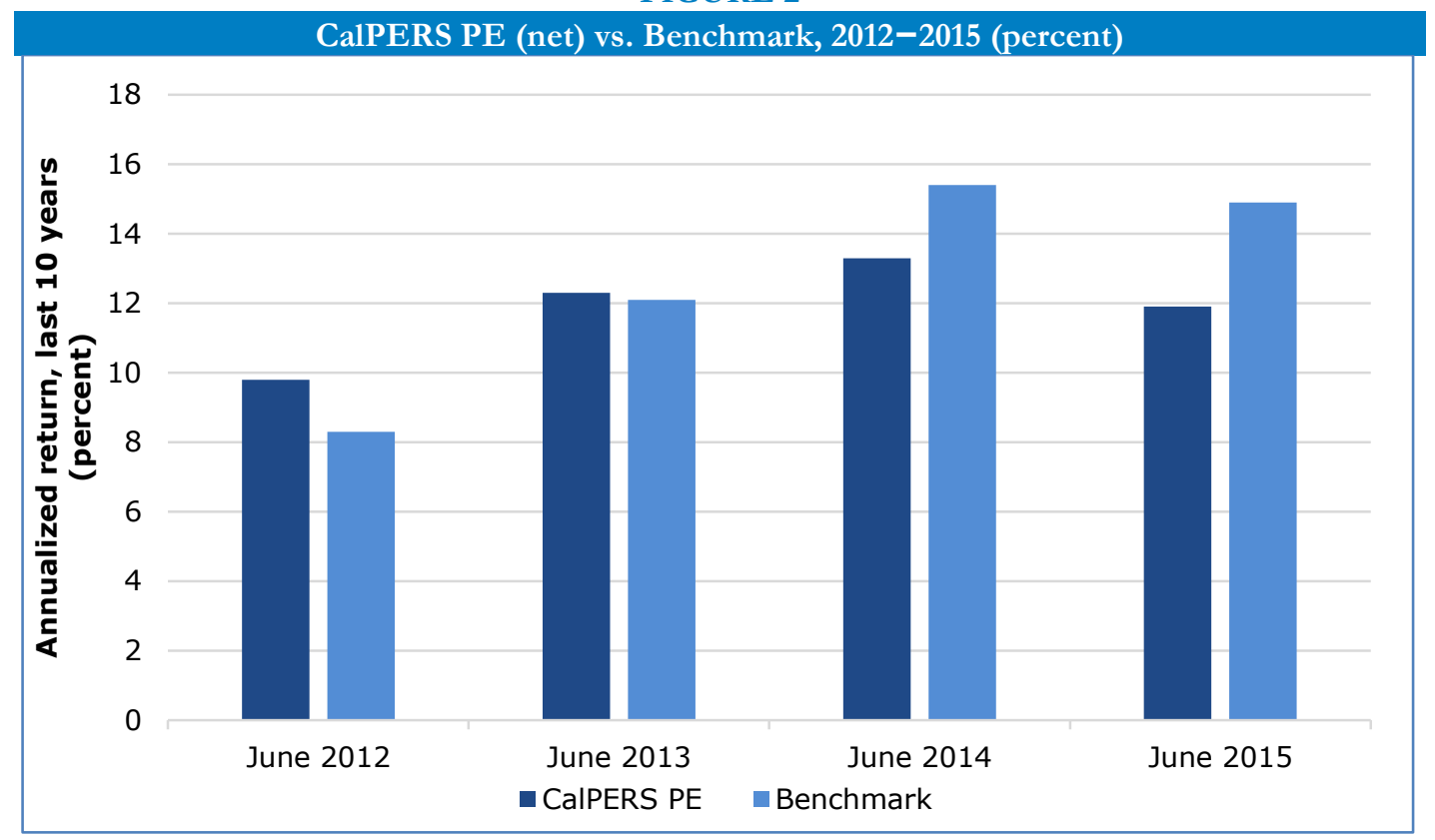

Source: CalPERS Comprehensive Annual Financial Report 2014, 2015.

As noted above, the question of which stock market index pension funds should use in establishing the benchmark is also a matter of controversy. Recalling the opportunity cost argument — that the performance of investments in private equity should be compared to the investor's next best alternative — suggests that the stock market index should reflect the range of publicly traded stocks in which the pension fund has invested. The S\&P 500 (or Russell 3000) would be appropriate for an investor that has mainly invested in large (or mid-cap) domestic stocks, with little to no exposure to global equities. It would not be appropriate for an investor with significant investments in foreign stocks. Pension funds that, like CalPERS, have invested in foreign stocks should judge PE performance, as CalPERS does, against a benchmark that includes these stocks.

\section{PE Buyout Fund Returns and Pension Fund Investments in Private Equity}

Finance economists have demonstrated the superiority of the Public Market Equivalent, which takes into account the timing and magnitude of actual cash flows, compared to the IRR as a measure of PE fund performance. Most pension funds (or their consultants) could calculate the PME and at least some do. Nevertheless, end-to-end IRRs are the private equity industry's standard and are widely used by pension funds in reporting returns. This makes it difficult for pension funds to know 
how this asset class is actually performing and can sometimes obscure a weakening in recent performance. Recent studies by finance economists show that returns from investing in PE buyout funds have declined over the last two decades, and the median fund in recent vintages just matches the performance of the S\&P 500. Some pension funds are beginning to recognize that recent performance is not likely to be as strong as in earlier periods.

Academic studies suggest that most investors in private equity buyout funds will find the superior performance PE firms promise elusive; for most, PE returns now more or less match the market. In view of the negative impact on workers of leveraged buyouts — including the focus of buyout funds on cutting labor costs in their portfolio companies and the higher likelihood of bankruptcy of those portfolio companies due to the increased debt levels (documented in Appelbaum and Batt 2014), employee pension funds, university endowments, and other investors with a broad public purpose require a compelling reason to invest in buyout funds. In the past, the promise of high returns served to justify investing in PE buyout funds. Today, promises of high returns are mostly empty.

\section{Conclusion: What Lies Ahead for PE Fund Performance?}

Stock market volatility in the first half of 2016 exposed the headwinds that the PE industry faces and the difficulty PE buyout funds are expected to have delivering strong returns in the future. A sharp drop in profits, including the unrealized value of companies in PE fund portfolios, triggered an industry-wide sell-off of shares and a sharp drop in share price in the first half of 2016. The Financial Times reported that shares of Apollo and Carlyle had fallen by two-thirds from their 2014 peaks, KKR's stock had fallen by half, and Oaktree's by 30 percent. ${ }^{15}$ Six of the nine publicly-traded PE firms - American Capital, Apollo, Ares Management, Blackstone, Carlyle, and Fortress Investment Group - were trading below their IPO opening price as of May, 2016, according to a PitchBook analysis; only Main Street Capital, KKR, and Oaktree Capital were trading higher than their opening price. ${ }^{16}$ As The Financial Times observed, this means “... that investors are effectively entirely discounting their future performance fees, or the share of profit the [private equity] groups take alongside investors in their funds when they exit successful deals ...." ${ }^{17}$ Performance fees — also known as carried interest - fuel the earnings of these PE firms and are used to pay dividends to shareholders. The sharp declines in share prices reflect the belief that distributions and returns are likely to fall.

15 Cotterill and Childs (2016).

16 Dowd (2016).

17 Cotterill and Childs (2016). 
Indeed, this is a view that is shared by leaders in the industry, who are hard at work trying to manage expectations down. Speaking at a Milken Institute conference in May 2016, a panel of private equity industry titans - Leon Black of Apollo Global Management, Jonathan Nelson of Providence Equity Partners, David Rubenstein of The Carlyle Group, and Robert Smith of Vista Equity Partners - warned that returns will be lower than in the past, distributions back to investors will decrease, and new PE buyout funds may have lives as long as 20 years. ${ }^{18}$

Yves Smith provides a cogent explanation for the dim view PE firm general partners and public investors in PE firms have been taking of unrealized, yet-to-be-earned, future profits and performance fees, which depend on successful exits from PE fund investments in portfolio companies. Smith highlights three developments that have transformed the tail winds that propelled PE firm profits in the post-financial crisis period into headwinds that may prove difficult to overcome: ${ }^{19}$

1. "Private equity has benefitted from a long-term trend of disinflation, from 1982 to 2008. It got an artificial extension due to central bank policies of ZIRP (zero interest rate policy) and QE [quantitative easing] giving them life beyond their natural sell-by date. Equity strategies, and even more, risky equity strategies like levered equity, as in private equity, will do particularly well under this scenario.

2. Private equity EBITDA multiples (prices paid to acquire companies for PE fund portfolios relative to the earnings of these companies) in the fourth quarter of 2015 were higher even than at the peak of the last cycle in 2007.

3. It's hard to see how any scenario going forward will be good for private equity. Central banks over the last six years have pushed investors into risky assets. Private equity will no longer have that tailwind. If interest rates go up (unlikely but not impossible) it will depress stock market valuations, increase the cost of borrowing, and make it harder to achieve high levels of leverage."

The buildup of near-record levels of unused capital - $\$ 460$ billion in dry powder in U.S. buyout funds - is a further headwind that threatens future PE fund performance. Near record highs in the stock market run-up in 2013-2014 and correspondingly high valuations of publicly traded companies enabled PE buyout funds to sell comparable portfolio companies at high prices. As Apollo chief Leon Black observed in 2013, PE funds were selling everything that wasn't nailed down. ${ }^{20}$ As noted earlier, pension funds and other institutional investors have ploughed those distributions and then some back into new PE buyout funds, without regard to whether PE returns

18 Jacobius (2016). See also Yves Smith (2016a).

19 Yves Smith (2016b).

20 Carey and Banerjee (2013). 
from recent vintages outperformed their stock market benchmarks. Capital flows into private equity have grown much faster than attractive target companies for PE acquisition. As PitchBook observed, "GPs are still able to raise ample amounts of capital, but the constant lack of targets to deploy that money continues to haunt many fund managers." ${ }^{21}$ The result has been a buildup of dry powder that raises the cost of private equity investing (Braun and Stoff 2016).

The upshot is that shareholders in publicly traded PE firms recognize that it will be difficult for private equity to repeat the strong distributions of 2013 and 2014. Credit to finance highly leveraged buyouts is more difficult to obtain as investors flee the junk bond market for high quality corporate and Treasury bonds and banks are more cautious lenders. Prices of attractive target companies have been bid up by competition for them among PE buyout funds with excess dry powder and newly raised funds, as well as with cash-rich corporations that see strategic value in owning them. And stock market volatility limits the ability to exit investments in portfolio companies via initial public offerings.

By 2016, some private equity firms were trying to shore up both share price and public confidence in their business model by buying back their own stock, although it is not clear that this is a confidence building measure. It may be seen, instead, as an admission that the PE firms lack profitable investment opportunities. In February, Carlyle reported a 59 percent decline in fourth quarter profits - a measure that includes unrealized gains. The PE giant simultaneously announced that it would buy back $\$ 200$ million worth of Carlyle shares. In this it joined Apollo and Fortress, which were buying back $\$ 250$ million and $\$ 100$ million worth of their own shares respectively, as well as Kohlberg Kravis Roberts \& Company, which in October, 2015 pledged to buy back as much as $\$ 500$ million worth of shares. ${ }^{22}$

Unlike public investors, pension funds and other institutional investors in private equity funds continue to be lulled into thinking that these investments will provide strong returns. Despite poor performance and excessive fees, pension funds and other investors continue to pour money into private equity funds. Blackstone's assets under management, which include the PE funds it sponsors, rose to a record $\$ 336.4$ billion in the first quarter of $2016 .^{23}$ The stock market's view of the future performance of publicly-traded PE firms suggests these investors are likely to be disappointed.

\footnotetext{
1 PitchBook (2016).

22 Stevenson (2016).

23 Jarzemsky (2016).
} 


\section{References}

American Investment Council (formerly PEGCC). 2016. "PE by the Numbers." Washington, D.C.: American Investment Council. http://www.investmentcouncil.org/private-equity-atwork/education/pe-by-the-numbers/.

Appelbaum, Eileen, and Rosemary Batt. 2014. Private Equity at Work: When Wall Street Manages Main Street. New York: Russell Sage Foundation Press.

https://www.russellsage.org/publications/private-equity-work.

—. 2016. "Fees, Fees and More Fees: How Private Equity Abuses Its Limited Partners and U.S. Taxpayers.” Washington, D.C.: Center for Economic and Policy Research. http:/ / cepr.net/publications/ reports/private-equity-fees-2016-05.

Bain \& Company. 2013. "Bain Global Private Equity Report 2013.” Boston, MA: Bain \& Company. http://www.bain.com/publications/articles/global-private-equity-report-2013.aspx.

— . 2016. "Bain Global Private Equity Report 2016.” Boston, MA: Bain \& Company. http://www.bain.com/publications/business-insights/global-private-equity-report.aspx.

Board of Governors of the Federal Reserve System, Federal Deposit Insurance Corporation and Office of the Comptroller of the Currency. 2013. "Interagency Guidance on Leveraged Lending." Washington, D.C.: Board of Governors of the Federal Reserve System. http://www.federalreserve.gov/bankinforeg/srletters/sr1303a1.pdf.

Braun, Reiner, and Ingo Stoff. 2016. "The Cost of Private Equity Investing and the Impact of Dry Powder." The Journal of Private Equity Vol. 19, No. 2, Spring, 22-33.

Braun, Reiner, Tim Jenkinson, and Ingo Stoff. 2015. "How Persistent Is Private Equity Performance? Evidence from Deal-Level Data." SSRN Working Paper. http:/ / ssrn.com/abstract=2314400.

CalPERS. 2015a. “California Public Employees’ Retirement System Investment Policy for Private Equity (PE) Program.” CalPERS December 14 Board Meeting, Agenda item 7a, Attachment 1. Sacramento, CA: CalPERS.

—. 2015b. "Comprehensive Annual Financial Report." Sacramento, CA: CalPERS.

Carey, David and Devin Banerjee. 2013. "Black’s Apollo 'Selling Everything' as Prices Have Risen." Bloomberg, April 30. http://www.bloomberg.com/news/articles/2013-04-30/black-sapollo-selling-everything-as-prices-have-risen.

Cohan, William D. 2015. “A private equity gamble in Vegas gone wrong.” Fortune Magazine, June 5. http://fortune.com/2015/06/05/caesars-losing-las-vegas/.

Cotterill, Joseph and Mary Childs. 2016. "Private Equity Groups under Pressure to Buy Own Stock." Financial Times, February 7. http://www.ft.com/intl/cms/s/0/d48d0394-cc1b11e5-a8ef-ea66e967dd44.html\#axzz404Ng3OaH. 
Davis, Michelle and Sridhar Natarajan. 2016. "Terms for Veritas LBO as Loans Reprice." Bloomberg, January29. http:/ / www.bloomberg.com/news/articles/2016-01-29/veritas-sloans-funding-carlyle-lbo-sweetened-as-markets-reprice.

Dowd, Kevin. 2016. "Private equity goes public: A history of PE stock performance." PitchBook, May 18. http://pitchbook.com/news/articles/private-equity-goes-public-a-history-of-pestock-performance.

Gottlieb, Jenna. 2011. “Establishing a Standard.” PE Manager, June 8.

Gredit, Oleg, Barry Griffiths, and Ruediger Stucke. 2014. "Benchmarking Private Equity: The Direct Alpha Method.” SSRN Working Paper. http:/ / ssrn.com/abstract=2403521.

Harris, Robert S., Tim Jenkinson, and Steven N. Kaplan. 2015. "How Do Private Equity Investments Perform Compared to Public Equity?” Darden Business School Working Paper No. 2597259. June 15. Forthcoming Journal of Investment Management. http://ssrn.com/abstract $=2597259$.

Harris, Robert S., Tim Jenkinson, Steven N. Kaplan and Ruediger Stucke. 2014. "Has Persistence Persisted in Private Equity? Evidence from Buyout and Venture Capital Funds." SSRN Working Paper. http:/ / ssrn.com/abstract=2304808.

Hawley, James, Keith Johnson, and Ed Waitzer. 2011. "Reclaiming Fiduciary Responsibility Balance." International Journal of Pension Management, Vol. 4, No. 2, 4-16.

Arleen Jacobius. 2016. "Private Equity Titans Warn Attendees to Expect Lower Returns." Pensions \& Investments, May 3. http:/ /www.pionline.com/article/20160503/ONLINE/160509958/private-equity-titanswarn-attendees-to-expect-lower-returns.

Jarzemsky, Matt. 2016. “Blackstone Thinks It’s Time to Buy.” Wall Street Journal, January 28. http:/ / www.wsj.com/articles/blackstone-profit-drops-on-challenging-volatile-markets1453984954.

Jenkinson, Tim, Miguel Sousa, and Rüdiger Stucke. 2013. "How Fair Are the Valuations of Private Equity Funds.” SSRN Working Paper. http:/ / ssrn.com/abstract=2229547.

Kaplan, Steven N., and Antoinette Schoar. 2005. "Private Equity Performance, Returns, Persistence, and Capital Flows." Journal of Finance Vol. 60, 1791-1823.

Kelleher, John C., and Justin J. MacCormack. 2004. "Internal rate of return: A cautionary tale." New York, NY: McKinsey \& Company. http:/ /www.mckinsey.com/business-functions/strategyand-corporate-finance/our-insights/internal-rate-of-return-a-cautionary-tale. 
L'Her, Jean-Francois, Rossitsa Stoyanova, Kathryn Shaw, William Scott and Charissa Lai. 2016. "A Bottom-Up Approach to the Risk-Adjusted Performance of the Buyout Fund Market." Financial Analysts Journal, Vol. 72, No. 4, 1-13.

Lim, Dawn. 2016. “Carlyle Gets Extension for Boom-Era Fund.” Wall Street Journal, March 10. http:/ /www.wsj.com/articles/carlyle-gets-extension-for-boom-era-fund-1457615027.

Lydenberg, Steve. 2012. "Reason, Rationality and Fiduciary Duty." New York: Investor Responsibility Research Center (IRRC).

Martin, Timothy W. 2015. “Calpers’ Private-Equity Fees: \$3.4 Billion.” Wall Street Journal, November 24. http:/ / www.wsj.com/articles/calpers-discloses-performance-fees-paid-toprivate-equity-managers-1448386229.

Maton, Brendan. 2010. “Dissecting ‘Absolute Returns’ Methods.” Financial Times, October 10. http:/ /www.ft.com/intl/cms/s/0/a985b8a2-d307-11df-9ae9-

00144feabdc0.html? siteedition $=u k \#$ axzz3mgBzI2IM.

Phalippou, Ludovic. 2009. “The Hazards of Using IRR to Measure Performance: The Case of Private Equity.” SSRN Working Paper. http:/ / ssrn.com/abstract=1111796.

Phalippou, Ludovic, and Oliver Gottschalg. 2009. “The Performance of Private Equity Funds.” Review of Financial Studies Vol. 22, 1747-1776.

PitchBook. 2014. "PitchBook 2Q 2014 Global PE \&VC Benchmarking \& Fund Performance Report." Seattle, WA: PitchBook.

—. 2015a. "PE + VC Fundraising and Capital Overhang Report: 2015 Annual." Seattle, WA: PitchBook.

—. 2015b. "PitchBook 3Q 2015 Global PE \&VC Benchmarking \& Fund Performance Report." Seattle, WA: PitchBook.

—. 2016. "PitchBook PE News, March 8, 2016." Seattle, WA: PitchBook.

Putnam Investments. “Absolute Return Investing.” Boston, MA: Putnam Investments. https://www.putnam.com/individual/mutual-funds/investment-strategies/absolute-returninvesting/different. Accessed June 13, 2016.

Robinson, David T., and Bert A. Sensoy. 2011, revision 2015. "Cyclicality, Performance Measurement, and Cash Flow Liquidity in Private Equity." Fisher College of Business, Ohio State University Working Paper Series. Dice Center WP 2010-021. Fisher College of Business WP 2010-03-021. http://ssrn.com/abstract=1731603.

Yves Smith. 2016a. "Smart Money Doing Private Equity in House as General Partners Warn of Lower Returns, Dumb Money Pours In.” Naked Capitalism, May 10. 
http:/ / www.nakedcapitalism.com/2016/05/smart-money-abandoning-private-equity-asgeneral-partners-warn-of-lower-returns-dumb-money-pours-in.html.

Yves Smith. 2016b. "Stock Market Investors Abandon Private Equity, Expect No Profits Overall From Current Deals.” Naked Capitalism. February 8.

http://www.nakedcapitalism.com/2016/02/stock-market-investors-abandon-private-equityexpect-no-profits-overall-from-companies-now-owned.html.

Stevenson, Alexandra. 2016. "Carlyle Group Reports Drop in Profit and Announces Stock Buyback." DealBook, The New York Times, February 10. http:/ / www.nytimes.com/2016/02/11/business/dealbook/carlyle-group-reports-drop-inprofit-and-announces-stock-

buyback.html?emc $=$ dlbkpm\&emc $=$ edit_dlbkpm_20160210\&nl= $\% 3 F$ nl $\% 3$ Ddlbk\&nlid $=707$ 26928.

Youngdahl, Jay. 2012. "The Time Has Come for a Sustainable Theory of Fiduciary Duty of Investment." Hofstra Labor and Employment Law Journal, Vol. 29, No. 115, 115-39. 